\title{
THE INFLUENCE OF ALLIIN ON ACTIN CYTOSKELETON REORGANIZATION IN H1299 CELL LINE IN THE PRESENCE OF LOW DOSES OF DOXORUBICIN
}

\author{
WPŁYW ALLIINY NA REORGANIZACJĘ CYTOSZKIELETU AKTYNOWEGO \\ KOMÓREK LINII H1299 W OBECNOŚCI NISKICH STĘŻEŃ DOKSORUBICYNY
}

\author{
${ }^{1}$ Students research group of Cell Biology and Ultrastructure at Department of Histology and Embryology, \\ Nicolaus Copernicus University in Torun, Collegium Medicum in Bydgoszcz \\ ${ }^{2}$ Departament of Histology and Embryology, Nicolas Copernicus University in Torun, Collegium Medicum in Bydgoszcz
}

S u m m a r y

\begin{abstract}
Alliin, garlic amino acid, has been thought to be pharmacologically inactive. However, several studies carried out on the cell cultures and the mammalian models demonstrated antioxidative and anticancer properties of alliin. Doxorubicin (DOX) is a well-known cytostatic agent, but often presented the side effects. Therefore, lowering a dose of DOX may reduce a negative influence of this drug on patients. The combined effect of DOX and alliin on the induction of cell death and the reorganization of actin cytoskeleton have not been yet tested in the human non-small cell lung cancer H1299 cells, thus the aim of the study was to evaluate the effects of DOX and alliin on the induction of
\end{abstract}

cell death, morphological and ultrastructural alterations, as well as the reorganization of F-actin in the H1299 cells, using image cytometry and light, fluorescence and transmission electron microscopy. The experimental results presented here indicate that alliin enhances DOX impact on H1299 cells in a dose-dependent manner by increasing the percentages of apoptotic cells and reducing the cell viability. It also led to Factin reorganization and both morphological and ultrastructural alternations. Alliin can support the tumoricidal effect of DOX but this potential therapeutic use should be examined in further studies.

\section{Streszczenie}

Alliina, aminokwas pochodzący $\mathrm{z}$ czosnku, przez lata była uważana za związek farmakologicznie nieaktywny. Jednakże badania prowadzona na kulturach komórkowych oraz modelach ssaczych dowiodły, że ma ona właściwości antyoksydacyjne i przeciwnowotworowe. Stosowanie cytostatyku doksorubicyny (DOX) w walce z nowotworami wiąże się $\mathrm{z}$ wieloma działaniami niepożądanymi, tak więc obniżenie dawki leku może stanowić sposób na zredukowanie toksyczności DOX. Dotychczas nie badano połączonych aktywności DOX i alliiny w indukcji apoptozy oraz reorganizacji cytoszkieletu aktynowego w komórkach niedrobnokomórkowego raka płuca linii H1299. Celem badania było określenie wpływu mieszaniny DOX i alliiny na indukcję apoptozy, a także na zmiany w morfologii, ultrastrukturze oraz organizacji F-aktyny w komórkach linii H1299 poprzez cytometrię obrazową, a także mikroskopie świetlną, fluorescencyjną oraz transmisyjną mikroskopię elektronową. Zaprezentowane w pracy wyniki wskazują, że alliina wzmacnia działanie doksorubicyny na komórki H1299 w zależności od wykorzystanej dawki, poprzez wzrost odsetka komórek apoptotycznych i redukcję przeżywalności komórek. Oba związki prowadzą do reorganizacji F-aktyny oraz zmian morfologicznych i ultrastrukturalnych. Alliina wspiera tym samym działanie antykancerogenne DOX, jednak jej potencjał terapeutyczny powinien zostać przedmiotem dokładniejszych badań. 


\section{INTRODUCTION}

Garlic is one of the most popular spices and cures around the world since the ancient times [1]. It consists of a wide range of sulfur compounds, such as amino acids represented by alliin, which was first isolated by Stool and Seebeck in 1948 [2]. Although alliin is the main compound found in garlic that accounts for $2 \%$ of its mass, the pharmacological activity of alliin has been questioned for many years and its role has seemed to be limited to serving as a substrate in enzymatic reactions. However, further studies have clearly shown that alliin exhibits a variety of biological activities, including antitumor, antioxidant and hypoglycemic effects. Using in vivo mice model, Stoll and Seebeck reported the inhibition of tumor growth following a direct injection of alliin. It has also been observed that alliin reduces angiogenesis in the chick chorioallantoic membrane (CAM) model as well as the basic stages of vessel growth such as endothelial cell (EC) tube formation [3]. In turn, the antioxidant properties of alliin have been shown to provide protection against oxidative damage in cardiovascular diseases [4]. This ingredient of garlic not only has direct antioxidant activity but may also increase the level of GSH and enhance antioxidative effects of vitamins and palladium as well $[3,5,6]$. Furthermore, the therapeutic potential of alliin is also believed to be associated with its capacity to decrease the serum glucose level, the effect of which has been observed in diabetic rats fed with alliin [7].

Doxorubicin (DOX) is the antineoplastic anthracycline antibiotic that was first isolated from Streptomyces peucetius early in the 1960s. Since then, it has become one of the most effective cytostatic agents for the treatment of various types of cancer, including breast, bladder or lung cancers, aggressive lymphomas, and tumors in children [8]. The cytotoxic effect of doxorubicin on tumor cells relies mainly on its ability to damage DNA through the direct intercalation with this molecule as well as the inhibition of topoisomerase II activity and the generation of reactive oxygen species (ROS). Furthermore, DOX has been shown to promote cell death as a consequence of upstream events such as the inhibition of topoisomerase II. There is evidence that the high concentrations of DOX trigger apoptotic cell death, whereas the low doses induce mitotic catastrophe and/or senescence $[9,10,11]$. However, in clinical practice, these responses are often accompanied by severe toxic side effects, especially cardiotoxicity, which restrict high dosage and longterm treatment of patients with doxorubicin [12].

Actin is one of the most abundant cellular proteins in eukaryotic cells and exists in two different forms, as a monomer (G-actin) and a polymer (F-actin). This protein as one of cytoskeleton elements is involved in many cellular processes, such as cytokinesis, differentiation and cell death. Microfilaments participate in secretion, cellular transport, motility of cells and carcinogenesis $[13,14,15,16]$. The course of these processes depends on the polymerization and depolymerization, which are regulated by actin-binding proteins [17]. Actin cytoskeleton is present not only in cytoplasm, but also in nucleus where it plays an important role in maintaining the structure and the function of these organelles. It is known that actin participates in gene expression because it constitutes a part of chromatin remodeling complex, such as mammalian BAF complex [15]. Nuclear actin is also associated with all three RNA polymerases (Pol I, II, III) and plays the role in transcription processes of Balbiani rings by RNA polymerase (RNAP II). Additionally, this protein is present in nucleoli where it participates with myosin in ribosomal subunits transport [18]. The localization of actin in cytoplasm and nucleus is clear, but what is important for new knowledge, it shows the balance between pools of actin in different cellular processes.

The aim of this study was to present the rearrangement of actin cytoskeleton in human nonsmall lung cancer cell line H1299 after the treatment with alliin, doxorubicin and the combination of these agents.

\section{MATERIAL AND METHODS}

\section{Cell culture and treatment}

The human non-small lung cancer cell line H1299 was purchased from American Type Culture Collection (Manassas, VA). The cells were grown in RPMI 1640 (Sigma-Aldrich) medium supplemented with $10 \%$ fetal bovine serum (FBS, Gibco) and $50 \mu \mathrm{g} / \mathrm{ml}$ gentamycin (Sigma- Aldrich) at $37^{\circ} \mathrm{C}$ in a humidified $\mathrm{CO}_{2}$ incubator for $24 \mathrm{~h}$. Next, cells were treated with alliin $10 \mu \mathrm{M}$, alliin $50 \mu \mathrm{M}$, DOX $0.5 \mu \mathrm{M}$, alliin $10 \mu \mathrm{M} /$ DOX $0.5 \mu \mathrm{M}$ and alliin $50 \mu \mathrm{M} /$ DOX $0.5 \mu \mathrm{M}$. Control cells were grown in the same conditions without the addition compounds to the medium. 


\section{Cell death analysis}

The determination of apoptotic and necrotic cell death was made using Tali Image-based cytometer (Invitrogen, Life Technologies) and Tali Apoptosis Kit (Invitrogen, Life Technologies) according to manufacturer's instructions. After incubation of cells with $10 \mu \mathrm{M}$ alliin, $50 \mu \mathrm{M}$ alliin, $0.5 \mu \mathrm{M}$ DOX, $10 \mu \mathrm{M}$ alliin / $0.5 \mu \mathrm{M}$ DOX and $50 \mu \mathrm{M}$ alliin / $0.5 \mu \mathrm{M}$ DOX. The cells were trypsynized and centrifuged. Next, the cells were incubated with $100 \mu \mathrm{L}$ Annexin binding buffer and $5 \mu \mathrm{L}$ of Annexin V Alexa Fluor 488 in the dark for $20 \mathrm{~min}$. After this time the cells were centrifuged and added again $100 \mu \mathrm{L}$ of Annexin binding buffer and $1 \mu \mathrm{L}$ of Propidium Iodine to each sample (RT, 3 min., in dark). The analysis was performed using Tali Image-based cytometer and FCS Express Research Edition software (Ver4.03; De Novo Software).

\section{Light microscopy}

The morphology of the cells was assessed by light microscope after hematoxylin staining. Cells were fixed with 4\% paraformaldehyde (pH 7.4, 20 min, RT, Serva, Germany) and rinsed with PBS (3 x 5 min) and $\mathrm{dH}_{2} \mathrm{O} \quad\left(\begin{array}{llll}5 & \mathrm{x} & 30 & \mathrm{~s}\end{array}\right)$. After staining with Mayer's hematoxylin (3 min, RT), rinsing under tap water and washing with PBS (10 min, RT), preparations were closed using Aqua PolyMount. Morphology of cell was observed using Eclipse E800 light microscope (Nikon) equipped with computer image analysis system (NISElements software 3.30) and CCD camera (DS-5Mc-U, Nikon).

\section{Transmission electron microscopy}

For observation of cells on the ultrastructural level, cells were fixed in $3.6 \%$ glutaraldehyde (30 min, RT), washed in cacodylic buffer and post-fixed $\mathrm{OsO}_{4}(1 \%$, $1 \mathrm{~h})$ in the same buffer. Next, cells were dehydrated in series of graded ethanol and acetone, and finally embedded in epoxy resin (Epon 812, Roth, Karlsruhe, Germany) with the addition of accelerator. After polymerization $\left(24 \mathrm{~h}\right.$ at $37^{\circ} \mathrm{C}, 120 \mathrm{~h}$ at $\left.65^{\circ} \mathrm{C}\right)$, material was cut into ultra-thin sections by using Richet Om U3 ultramicrotome (Reichert) and placed on copper grids (Sigma-Aldrich). Ultra-thin slices were contrasted in uranyl acetate and analyzed in transmission electron microscope JEM 100 CX (JEOL, Tokyo, Japan).

\section{Fluorescence microscopy}

For F-actin and nucleus labeling, H1299 cells grown on glass coverslips in 12-well culture plates and with fixed with $4 \%$ paraformaldehyde ( $\mathrm{pH} 7.4,20$ min,
RT, Serva, Germany). After fixation cells were washed with PBS ( 3 x 5 min, RT), incubated with $0.25 \%$ Triton X-100 (5 min, RT) and washed with PBS again (3 x $5 \mathrm{~min}, \mathrm{RT})$. Actin filaments were labeled by incubation with Alexa Fluor ${ }^{\circledR} 488$ conjugated with phalloidin (1:40, $20 \mathrm{~min}, \mathrm{RT})$. Next, cells were washed with PBS ( $3 \times 5 \mathrm{~min}, \mathrm{RT})$ and counterstained using DAPI (1:25.000, $10 \mathrm{~min}, \mathrm{RT})$. Finally, the cells were washed with PBS ( 3 x 5 min, RT) and mounted with Aqua PolyMount. The reorganization of F-actin was analyzed using Nikon Eclipse E800 fluorescence microscope (Nikon, Tokyo, Japan) supported with computer image analysis system (NIS-Elements software 3.30) and CCD camera (DS-5Mc-U, Nikon).

\section{Statistical analysis}

Statistical analysis was performed by the nonparametric Mann-Whitney U test in GraphPad Prism 6 $(P \leq 0.05$, GraphPad Software)

\section{RESULTS}

\section{Cell death analysis}

The analysis of cell death was performed using Tali Image-based cytometer and Tali Apoptosis Kit comprised of Annexin V-Alexa Fluore 488 and propidium iodide to identify cells undergo apoptotic cell death. The percentage of live cells was statistically significant decreased in concentration-dependent manner after treatment with $10 \mu \mathrm{M}$ alliin, $50 \mu \mathrm{M}$ alliin, $0.5 \mu \mathrm{M}$ DOX and combination of $10 \mu \mathrm{M}$ alliin / 0.5 $\mu \mathrm{M} \quad \mathrm{DOX}$ and $50 \mu \mathrm{M}$ alliin/0.5 $\mu \mathrm{M} \quad \mathrm{DOX}$ respectively(Fig. 1A).

As it has been shown in Fig. 1B, the percentage of apoptotic cells was increased after the incubation of H1299 cells with all compounds. The lowest level of cell viability and the highest percentage of cell death was observed after treatment of cells with the combined $50 \mu \mathrm{M}$ alliin and $0.5 \mu \mathrm{M}$ DOX (Fig 1 A,B). Moreover, in $\mathrm{H} 1299$ cells treated with $10 \mu \mathrm{M}$ alliin, 50 $\mu \mathrm{M}$ alliin, $0.5 \mu \mathrm{M}$ DOX and combination of $10 \mu \mathrm{M}$ alliin / $0.5 \mu \mathrm{M}$ DOX and $50 \mu \mathrm{M}$ alliin / $0.5 \mu \mathrm{M}$ DOX, no statistically significant differences in the percentage of necrotic cells were seen, as compared to the control (Fig. 1C). 

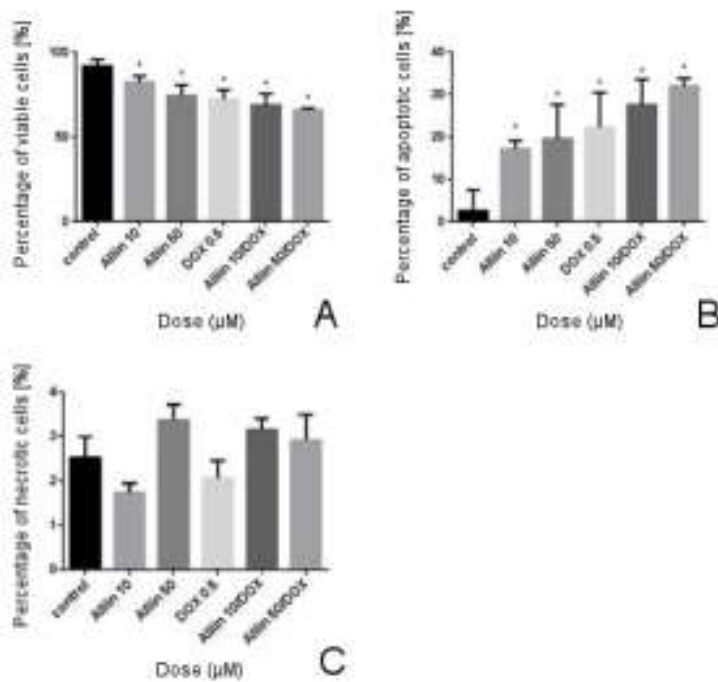

Fig. 1. The evaluation of cell viability and type of cell death in H1299 cell line after treatment with $10 \mu \mathrm{M}$ alliin, $50 \mu \mathrm{M}$ alliin, $0.5 \mu \mathrm{M} D O X$ and combination of $10 \mu \mathrm{M}$ alliin/0.5 $\mu M$ DOX and $50 \mu M$ alliin/0.5 $\mu M D O X$. Athe percentage of viable cells; $B$ - the percentage of apoptotic cells; $C$ - the percentage of necrotic cells. Statistical differences were marked with asterisk ( $P<0.05 ;$ Mann-Whitney U test)

Ryc. 1. Ocena przeżywalności komórek oraz rodzaju śmierci komórek w linii komórkowej H1299 po traktowaniu w obecności $10 \mu \mathrm{M}$ oraz $50 \mu \mathrm{M}$ alliiny, $0.5 \mu \mathrm{M}$ doksorubicyny oraz ich mieszanin. A - spadek liczby komórek żywych $w$ kolejnych próbach; $B$ - wzrost odsetka komórek apoptotycznych; $C$ - niewielki odsetek komórek nekrotycznych. $P \leq 0,05$; * - istotność statystyczna

\section{Morphological changes}

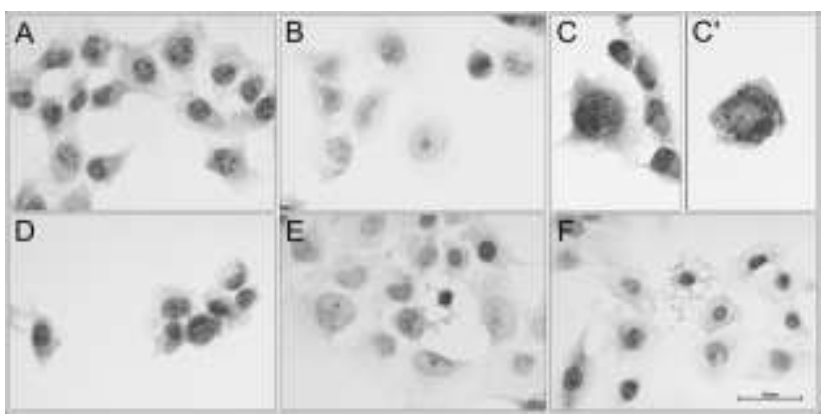

Fig. 2. The effect of alliin and DOX on the morphology of H1299 cells. A - control; $B-10 \mu M$ alliin; $C, C^{\prime}-50$ $\mu M$ alliin. $D-0.5 \mu M D O X ; E-10 \mu M$ alliin / $0.5 \mu M$ DOX. F - $50 \mu M$ alliin / $0.5 \mu M$ DOX. Bar $=50 \mu \mathrm{m}$.

Ryc. 2. Wptyw alliiny $i$ doksorubicyny na morfologie komórek linii H1299. A- kontrola; $B-10 \mu M$ alliina; C, $C^{\prime}-50 \mu M$ alliina. D - 0,5 $\mu M$ DOX; $E-10 \mu M$ alliina /0,5 $\mu M$ DOX. F $-50 \mu M$ alliina / 0,5 $\mu M$ DOX. Bar $=50 \mu \mathrm{m}$.

The H1299 control cells are polyhedral with oval or kidney-shape nucleus (Fig. 2A). There were no morphological differences after the treatment of cells with the lowest dose of alliin (Fig. 2B). In turn, a higher dose of the amino acid $(50 \mu \mathrm{M})$ induced nuclear segmentation (Fig. 2C') and the formation of giant cells with a big nucleus as well (Fig. 2C). The treatment of cells with doxorubicin also induced nuclear segmentation (Fig. 2D), but after using the combination of alliin and DOX, the shrunken cells with condensed chromatin and enlarged mononucleated cells were observed (Fig. 2E). The incubation of cells with the combination of these agents had resulted in the formation of branched cytoplasmic protrusions (Fig. 2 E,F). The transmission electron microscopic analysis confirmed the occurrence of both above described cellular phenotypes. Control cells were round with non-segmented nucleus (Fig. 3A). After the treatment with alliin, we observed the cells with nuclear segmentation, swollen mitochondria and vacuoles (Fig. 3B,C).

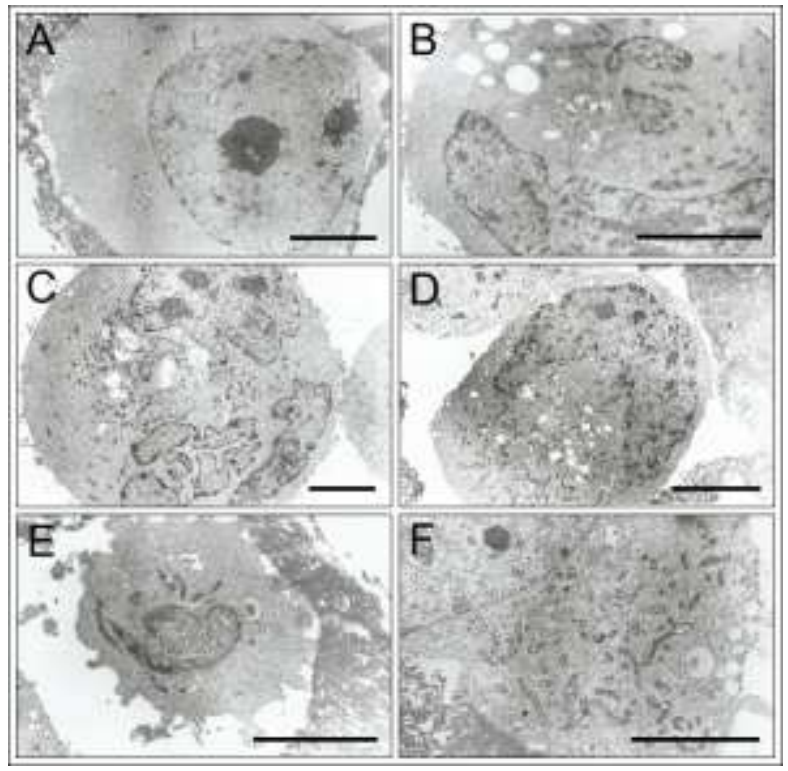

Fig. 3. The influence of alliin and doxorubicin on the ultrastructure of $H 1299$ cells. A - control; $B-10 \mu M$ alliin; $C-50 \mu M$ alliin. $D-0.5 \mu M D O X ; E-10 \mu M$ alliin / $0.5 \mu M$ DOX. F - $50 \mu M$ alliin / $0.5 \mu M$ DOX. Bar $=5 \mu \mathrm{m}$

Ryc. 3. Wplyw alliiny $i$ doksorubicyny na ultrastrukture komórek linii H1299. A - kontrola; B $-10 \mu M$ alliina.; $\quad C \quad-50 \quad \mu M$ alliina. $D \quad-0,5 \quad \mu M$ doksorubicyna. $E-10 \mu M$ alliina / 0,5 $\mu M D O X$; F$50 \mu M$ alliina / 0,5 $\mu M$ DOX. Bar $=5 \mu m$

As shown in Fig. 3D, doxorubicin induced the formation of vacuoles and kidney-shape nucleus. After the treatment with the composition of alliin and doxorubicin the shrunken cells with condensed chromatin and apoptotic body formation were observed. Additionally, giant cells with swollen mitochondria were noticed (Fig 3 E,F). 


\section{F-actin reorganization}

The fluorescence analysis of F-actin revealed the characteristic architectural changes after the treatment of H1299 cells with alliin and doxorubicin. The control cells exhibited well-development stress fibers and the accumulation of short polymers in the nuclear area. Fluorescent staining of actin filaments revealed an increase in fluorescent labelling of F-actin in the place of cell-cell contact (Fig. 4 A). A similar staining pattern was observed after the treatment with $10 \mu \mathrm{M}$ alliin (Fig. 4B). After the incubation with the highest dose of alliin, enlarged cells with thick, cortical stress fibers and the cells with the accumulation of short Factin polymers in the nuclear area were noticed (Fig. 4C). Doxorubicin induced the segmentation of nucleus, but the radical changes after the incubation with the composition of alliin and DOX were seen (Fig.4D-E). In the giant, multinucleated cells, F-actin was observed as the short fibers in the cytoplasm. Besides, the accumulation of actin filaments as a ring surrounding the nucleus was also noticed (Fig. 4E,F).
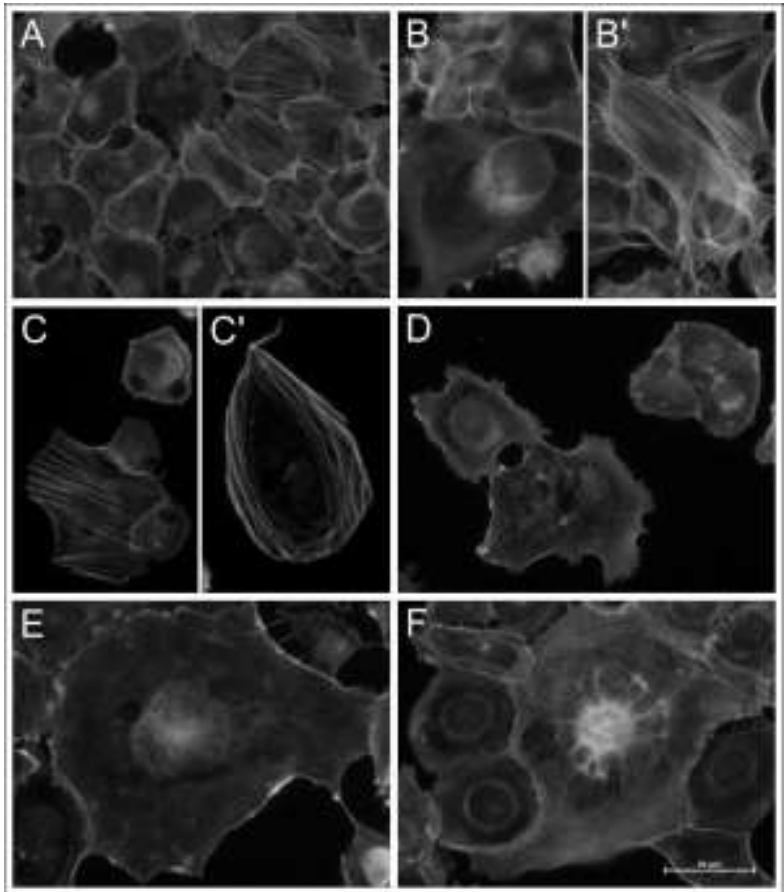

Fig. 4. The effect of alliin and doxorubicin on F-actin organization in the $H 1299$ cell line. A - control; $B, B^{\prime}-10 \mu M$ alliin; $C, C^{\prime}-50 \mu M$ alliin. $D-0.5 \mu M$ DOX; $E-10 \mu M$ alliin / $0.5 \mu M$ DOX. F - $50 \mu M$ alliin / $0.5 \mu M$ DOX. Bar $=50 \mu \mathrm{m}$

Ryc. 4. Wpływ alliiny $i$ doksorubicyny na organizacje $F$ aktyny w komórkach linii H1299.. A - kontrola; B, $B^{\prime}-10 \mu M$ alliina.; $C, C^{\prime}-50 \mu M$ alliina.; $D-0,5$ $\mu M$ doksorubicyna. E- $10 \mu M$ alliina / 0,5 $\mu M D O X$; F-50 $\mu$ M alliina / 0,5 $\mu$ M DOX.. Bar $=50 \mu \mathrm{m}$

\section{DISCUSSION}

Lung cancer is a leading cause of death among cancer patients. As well as the other types of neoplasm, it develops a resistance to drugs. This feature forces to find new substances for the lung cancer treatment. Garlic-derived sulfur compounds are thought to be the potential candidates in anticancer therapy through their proapoptotic activity that was shown in prostate, colon and lung cancer cell lines [8]. Diallyl sulfide (DAS), derived from garlic extract, promoted cell death in NCI-H460 and NCI-H1299 cell lines, whereas diallyl disulfide (DADS) induced cell cycle arrest and apoptosis in all mentioned lung cancer cell lines $[19,20]$. These reports are consistent with our studies since we also observed the induction of apoptosis in H1299 cell line at concentrations of $10 \mu \mathrm{M}$ and $50 \mu \mathrm{M}$ alliin that has never been examined in mentioned cell line before. While alliin induces apoptosis in cancer cells, it protects normal cells from programmed cell death and oxidation, according to the studies carried out on rat cardiomiocytes [21].

Doxorubicin was the second agent employed in our study. Several researches showed that this cytostatic can induced, according to the concentration, two different types of cell death: apoptosis and mitotic catastrophe. In human hepatoblastoma Huh-7 cells, A549 and Chinese hamster ovarian CHO AA8 cells, low doses of doxorubicin promoted mitotic catastrophe and high doses- apoptosis [9,22,23]. In our study, 0.5 $\mu \mathrm{M}$ DOX induced $22.53 \%$ apoptotic cells in H1299 cell line. The percentage of apoptotic cell increased after the treatment of H1299 cells with alliin/doxorubicin combinations $(27.65 \%$ for $10 \mu \mathrm{M}$ alliin / DOX and $32.08 \%$ for $50 \mu \mathrm{M}$ alliin / DOX), what suggested that alliin enhanced doxorubicin effect. Similar effect was achieved in combination of DOX and P276-00 (small molecule inhibitor of cyclindependent kinases) in H1299, H23, and H460 nonsmall cell lung cancer cell lines [24]. Both light and transmission electron microscopy confirmed that alliin, DOX and their combinations induced apoptosis and mitotic catastrophe in H1299 cells. Formation of giant, mono- or multinucleated cells, probably cells exhibiting morphological features of mitotic catastrophe were observed. On the light and electron microscope level, we noticed also apoptotic, shrunken cells with condensed chromatin.

Our results suggested a dose-dependent effects of alliin, doxorubicin and combinations of these 
substances on the viability, morphology and ultrastructure of the human non-small lung cancer cell line H1299. This study also presented the reorganization of actin filaments, which are connected with cell condition. The previous study presented a key role of actin in apoptosis, where is located in the place of apoptotic body formation [25]. We also know that localization of actin in nucleus is a condition to apoptosis process [15]. Additionally, a lack of Actb gene in mice embryos, which encodes actin isoform, prohibited a cell growth and migration [26]. On the other hand, viliin and gelsolin's deletion led to actin reorganization and finally to gastrointestinal epithelial cell death [27]. In CHO AA8 and A549 cell lines treated with DOX, actin underwent reorganization $[11,28]$. Our results confirmed data obtained by Grzanka et al. who also observed a tendency to multinucleated cells formation after treatment with 0.5 $\mu \mathrm{M}$ DOX [28]. Higher DOX concentrations (1 and 2.5 $\mu \mathrm{M})$ induced apoptosis, what we also noticed in our study during incubation of cells with alliin and DOX [28]. Taking into account our results, we suggested that alliin enhanced doxorubicin effect to promote an increase in the number of apoptotic cells.

The formation of thickened stress fibers constituted the characteristic effect of alliin in H1299 cells, whereas low-dose doxorubicin treatment caused the reorganization of F-actin cytoskeleton into short polymers diffused in the body of cell, as well as combination of alliin and DOX. The stress fibers loss in H1299 cells was also observed in the condition of hyperthermia, suggesting that both chemical and physical stress influences the non-small cell lung cancer cells ability to bundle F-actin filaments [29].

In the light of previous studies, alliin, as a natural substance, has safe and beneficial influence on health. Oral administration of this amino acid in rats showed $16.5 \%$ bioavailability, therefore there is a possibility that other mammalian organisms will distribute alliin similarly. What is more, alliin was present in rat liver; thus, it did not undergo an enzymatic reaction to alliicin during metabolism [21]. Cardioprotective and antioxidative activity of alliin may provide a support for traditional anticancer therapies and a protection from ROS generation under doxorubicin treatment.

In conclusion, we obtained the results confirming biological activity of alliin in H1299 non-small lung cancer cell line. Both light and transmission electron microscopy revealed the traits of apoptosis and mitotic catastrophe in cells treated with alliin, whereas fluorescence microscopy confirmed that actin cytoskeleton undergoes rearrangement in the presence of the sulphur compound. What is more, alliin enhances doxorubicin-induced effects in H1299 cells such as decreasing cell viability, inducing cell death, and F-actin reorganisation. The similarities between results obtained from higher DOX concentrations and lower doses of DOX supported by alliin in H1299 cells suggests the hypothetical benefits of alliin supplementation in lung cancer patients treated with cytostatics.

\section{REFERENCES}

1. Chanda S, Kushwaha S, Tiwari RK: Garlic as food, spice and medicine: a perspective. J Pharm Res, 2011; 4: $1857-1860$

2. Stoll A, Seebeck E: Chemical investigations of alliin, the specific principle of garlic. Adv Enzymol Relat Area Mol Biol, 1951; 11: 377-400.

3. Mousa AS, Mousa SA: Anti-Angiogenesis Efficacy of the Garlic Ingredient Alliin and Antioxidants: Role of Nitric Oxide and p53. Nutr. Cancer, 2005; 53: 104110.

4. Sangeetha T, Quine SD: Preventive effect of S-allyl cysteine sulphoxide (Alliin) on mitochondrial dysfunction in normal and isoproterenol induced cardiotoxicity in male Wistar rats: a histopathological study. Mol Cell Biochem, 2009; 328: 1-8.

5. Augusti KT, Sheela CG: Antiperoxide effect of S-allyl cysteine sulfoxide, an insulin secretagogue, in diabetic rats. Experientia, 1996; 52: 115-119.

6. Abbehausen $C$, Sucena SF, Lancellotti $M$ et al.: Synthesis, spectroscopic characterization, DFT studies, and antibacterial and antitumor actvities of a novel water soluble $\mathrm{Pd}(\mathrm{III})$ complex with L-alliin. J Mol Struct, 2013; 1035: 421-426.

7. Nasim SA, Bhupinder D, Rashmi $K$ et al.: Alliin obtained from leaf extract of garlic grown under in situ conditions possess higher therapeutic potency as analyzed in alloxan-induced diabetic rats. Pharm Biol, 2011; 49: 416-421.

8. Singhal SS, Wickramarachchi D, Singhal J et al.: Determinants of differential doxorubicin sensitivity between SCLC and NSCLC. FEBS Lett, 2006; 580: 2258-64.

9. Eom, YW, Kim MA, Park SS et al.: Two distinct modes of cell death induced by doxorubicin: apoptosis and cell death through mitotic catastrophe accompanied by senescence-like phenotype. Oncogene. 2005; 24 : 4765-77.

10. Park SS, Eom YW, Choi KS: Cdc2 and Cdk2 play critical roles in low dose doxorubicin-induced cell death through mitotic catastrophe but not in high dose doxorubicin-induced apoptosis.Biochem Biophys Res Commun 334: 1014-1021, 2005. 
11. Litwiniec A, Grzanka A, Helmin-Basa A et al.: Features of senescence and cell death induced by doxorubicin in A549 cells: organization and level of selected cytoskeletal proteins. J. Cancer Res. Clin. Oncol. 2010; 136: 717-36.

12. Tacar O, Sriamornsak P, Dass CR: Doxorubicin: an update on anticancer molecular action, toxicity and novel drug delivery systems. J Pharm Pharmacol, 2013; 65: $157-170$.

13. Dos Remedios CG, Chhabra D, Kekic, et al.: Actin Binding Proteins: Regulation of Cytoskeletal Microfilaments. Physiol Rev, 2003; 83: 433-73.

14. Pollard TD, Blanchoin L, Mullings RD: Molecular Mechanisms Controlling Actin Filament Dynamics in Nonmuscle Cells. Annu Rev Biophys Biomol Struct, 2000; 29: 545-76.

15. Grzanka D, Gagat M, Izdebska, M: Actin is required for cellular death. Acta Histochem, 2013; 115: 775782.

16. Pollard TD, Cooper JA: Actin, a Central Player in Cell Shape and Movement. Science, 2009; 326: 1208-1212.

17. Chhabra ES, Higgs HN: The many faces of actin: Matching assembly factors with cellular structures. Nature Cell Biology, 2007: 9; 1110-1121.

18. Cisterna B, Necchi D, Prosperi E, et al.: Small ribosomal subunits associate with nuclear myosin and actin in transit to the nuclear pores. FASEB J. 2006;20:1901-1903.

19. Wu XJ, Kassie F, Mersch-Sundermann V: The role of reactive oxygen species (ROS) production on diallyl disulfide (DADS) induced apoptosis and cell cycle arrest in human A549 lung carcinoma cells. Mutat Res, 2005; 579:115-24.

20. Chung LY: The antioxidant properties of garlic compounds: allyl cysteine, alliin, allicin and allyl disulfide. J Med Food, 2006; 9: 205-213.

21. Louis XL, Murphy R, Thandapilly SJ, et al.: Garlic extracts prevent oxidative stress, hypertrophy and apoptosis in cardiomyocytes: a role for nitric oxide and hydrogen sulfide. BMC Complement Altern Med, 2012; 12:140.

22. Grzanka D, Domaniewski J, Grzanka A: Effect of doxorubicin on actin reorganization in Chinese hamster ovary cells. Neoplasma, 2005; 52: 46-51.
23. Chrustek A, Izdebska M, Hałas M, et al.: The influence of doxorubicin on nuclear and cytoplasmic pool of Factin in the A549 cell line. Med.Biol.Sci, 2014; 28: 1117.

24. Rathos MJ, Khanwalkar H, Joshi K et al.: Potentiation of in vitro and in vivo antitumor efficacy of doxorubicin by cyclin-dependent kinase inhibitor P27600 in human non-small cell lung cancer cells. BMC Cancer. 2013; 13: 29.

25. Grzanka A, Grzanka D, Orlikowska M. Cytoskeletal reorganization during process of apoptosis induced by cytostatic drugs in K-562 and HL-60 leukemia cell lines. Biochem Pharmacol. 2003;66:1611-1617

26. Bunnell TM, Burbach BJ, Shimizu Y, et al. $\beta$-Actin specifically controls cell growth, migration, and the Gactin pool. Mol Biol Cell, 2011; 22: 4047-4058

27. Wang, Y, George SP, Srinivasan K et al.: Actin reorganization as the molecular basis for the regulation of apoptosis in gastrointestinal epithelial cells. Cell Death Differ, 2012; 19: 1514-24.

28. Grzanka D, Marszałek A, Gagat M et al.: Doxorubicininduced F-actin reorganization in cofilin-1 (nonmuscle) down-regulated $\mathrm{CHO}$ AA8 cells. Folia Histochem Cytochem, 2010; 48: 377-86.

29. Pawlik A, Nowak JM, Grzanka D et al.: Hyperthermia induces cytoskeletal alterations and mitotic catastrophe in p53-deficient H1299 lung cancer cells. Acta Histochem, 2013; 115: 8-15.

\section{Address for correspondence:}

Magdalena Izdebska

Nicolaus Copernicus University in Toruń

Collegium Medicum in Bydgoszcz

Department of Histology and Embryology

24 Karłowicza St., 85-092 Bydgoszcz, Poland

Phone: +48 525853723

e-mail: mizdebska@cm.umk.pl

Received: 12.12.2014

Accepted for publication: 17.03.2015 